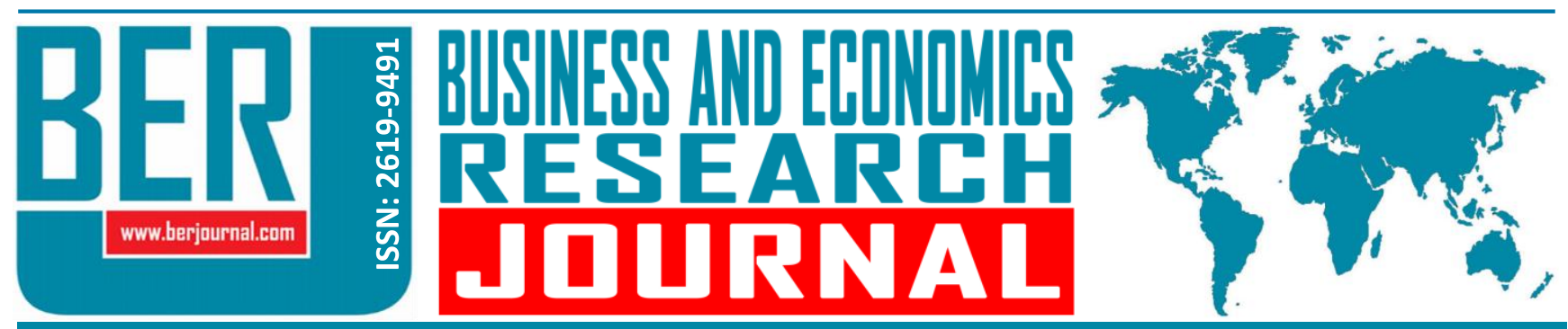

Business and Economics Research Journal Vol. 11, No. 2, 2020, pp. 413-429 doi: 10.20409/berj.2020.258

\section{BRICS-T Ülkelerinde Risk Priminin Belirlenmesinde Ülke Kredi Notları ve Kredi Temerrüt Swapı Primlerinin Karşılaştırmalı Analizi}

\author{
Tansu Kutuk ${ }^{\mathrm{a}}$, Mustafa Okur ${ }^{\mathrm{b}}$
}

Öz: Kredi notlarının uluslararası piyasalardan sağlanan fonların maliyetleri üzerinde ciddi etkileri vardır. Bu bakımdan, özellikle gelişmekte olan ülkeler açısından kredi notlarının güvenilirliği ve tarafsızlığı çok önemlidir. Bu çalışmanın amacı ülke ve kurumlara ait kredi notlarıın ne kadar gerçek durumu yansıttığını, değerlendirme süreçlerinin ne kadar şeffaf olduğunu ve ne derece güvenilir olduğunu ortaya koymaktır. Kredi notlarının etkisinin araştırılması amacıyla; BRICS-T ülkelerinin makroekonomik verileri, CDS primleri ve bankacılık-finans endeksleri alınarak; notların değişim öncesi ve sonrası değerlendirilmiş, tablo ve grafikler yardımılla analiz edilmiştir. Bu aşamada kredi notlarının bankacılık sektörüne etkisini analiz etmek amacıyla; her ülkeden halka açık bankalar seçilmiş, bu bankaların hisse fiyatları ve mali oranlarındaki değişim incelenerek, banka ve ülke notu birlikte değerlendirilmiştir. Çalışmada kredi derecelendirme notları yerine CDS primlerindeki hareketlerin dikkate alınmasının, ülkenin ve bankanın kredi güvenilirliğini daha gerçekçi bir şekilde yansıttığına dair görüşler aktarılmıştır. Yapılan analizlerin sadece Türkiye ile sınırlandırılmaması, analizlere BRICS ülkelerinin de katılması çalışmayı gerek ulusal gerekse uluslararası literatürdeki diğer çalışmalardan farkılışstırmaktadır.

\section{A Comparative Analysis of Country Ratings and Credit Default Swap Premiums in Determining Risk Premium in BRICS-T Countries}

\begin{abstract}
Sovereign credit ratings have a significant impact on the costs of funds obtained from international markets. In this respect, the reliability and impartiality of credit ratings are very important, especially for developing countries. The aim of this study is to reveal how real the credit ratings of countries and institutions reflect the existing situation, how transparent and reliable the evaluation processes are. In order to investigate the effect of credit ratings; macroeconomic data, CDS premiums and banking-finance indices of BRICS-T countries were evaluated before and after the rating changes and analyzed with the help of tables and graphs. At this point, in order to analyze the impact of credit ratings to the banking sector; the selected public bank's and country's ratings were evaluated by analyzing the change in share prices and financial ratios of these banks. It was evidenced that movements in CDS premiums reflect the credit reliability of countries and the banks more realistically than the credit ratings. By extending the scope of the study with BRICS countries we differentiated if from the previous literature. In this regard, also an international dimension was added to the study.
\end{abstract}

Anahtar Sözcükler: Kredi Derecelendirme, BRICS Ülkeleri, Kredi Temerrüt Swapları

JEL: G15, G20, G21

$\begin{array}{ll}\text { Geliş } & : \text { 14 Kasım } 2019 \\ \text { Düzeltme } & : \text { : } 2 \text { Ocak } 2020 \\ \text { Kabul } & : \text { 15 Ocak } 2020 \\ & \\ \text { Tür } & : \text { Araştırma }\end{array}$

Keywords: Credit Ratings, BRICS Countries, Credit Default Swaps (CDS)

JEL: G15, G20, G21

Received : 14 November 2019 Revised : 02 January 2020 Accepted : 15 January 2020

Type : Research

Specialist, Kare Portfolio Management, Istanbul, Turkiye, Tansu.Kutuk@kareportfoy.com.tr (ORCID ID: 0000-0001-6228-9506)

a Assoc. Prof., PhD., Marmara University, School of Banking and Insurance, Department of Capital Markets, Istanbul, Turkiye, mustafaokur@marmara.edu.tr (ORCID ID: 0000-0003-3121-8603) 


\section{Giriş}

Küresel sermayeye ulaşım, özellikle gelişmekte olan ülke ekonomilerinin amaçladıkları makroekonomik hedeflere ulaşmasının önündeki kaynak yetersizliği sorunu için önemli bir engeldir. Bu sebepten ağırlıklı olarak gelişmekte olan ülkeler uluslararası dolaylı ve doğrudan yatırımları ülkelerine çekmek isterler. Fonlarını uluslararası piyasalarda değerlendirmek isteyen yatırımcılar yatııım yapmadan önce yatırım yapacakları ülke ya da firma hakkında bilgi sahibi olmak isterler; işte bu noktada uluslararası kredi derecelendirme kuruluşları devreye girmektedir.

Derecelendirme; bir kuruluşun, yükümlülüklerini zamanında ve eksiksiz yerine getirebilmesine yönelik riski yansıtan görüş olarak tanımlanabilir. Derecelendirme işlemi sonucunda, kuruluşun belirlenen kredi değerliliği, evrensel ve anlaşııması kolay bir takım harf ve sayılardan oluşan sembollerle ilan edilir. Kredi derecelendirme kuruluşları tarafından birtakım ekonomik ve politik faktör ışığında gerekli risk değerlendirmesi yapıldıktan sonra, uzun vadeli yabancı para cinsinden açıklanan alfa numerik sonuçlara kısaca "ülke kredi notu" (sovereign credit rating) adı verilmektedir. Dünya genelinde faaliyet gösteren ve yüksek bilinirliği olan üç büyük kuruluş vardır. Bunlar; Standar\&Poor's (S\&P), Moody's ve Fitch Ratings (Fitch)'dir. Kredi derecelendirme kuruluşları genel olarak verdikleri notların görüş niteliğinde olduğunu savunsa da dünya sermaye hareketliliği büyük oranda bu kuruluşların vermiş oldukları notlar yönünde oluşmaktadır. Finansal sistemde yaşanan hareketlilikleri ve sermaye akışının yönünü kredi derecelendirme kuruluşları belirlemektedir. Ülkenin derecelendirme hizmeti satın alması sonucu, elde edeceği kaliteli bir kredi notu ülkeye birçok fırsat yaratmaktadır. Ekonomik olarak büyümek ve uluslararası sistemde söz sahibi olmak her ulusun hedeflerindendir. Büyüme; yaşam standartlarını artırmak, ulusal güvenliği temin etmek ve uluslararası alanlarda prestij sağlamak gibi birçok imkan oluşturmaktadır (Dinler, 2015). Derecelendirme, ülkeler için borçlanma işleminin maliyetini ve risk primlerini düşürme yöntemidir. Derecelendirme neticesinde faiz hadlerinde yaşanan değişmeler sebebiyle, sermaye hareketliliği yaşanmaktadır. Bu sebeple ülke notunun yüksek olması ekonomik açıdan çok önemlidir. Uluslararası kuruluşlar tarafından verilen kredi dereceleri ise ülkelerin global finans piyasalarına ulaşabilmelerinde ve finansman koşullarında etkilidir (Reinhart, 2002). Son yıllarda sermaye hareketlerinin dünya ticaretine yön verici etkiye sahip olmasından dolayı bu kuruluşlar küresel ölçekte stratejik aktörler haline gelmişlerdir. Bu noktada günümüze özellikle hükümetler ve ekonomi camiası tatmin edici olmayan ülke notlarına önemli ölçüde tepki göstermektedirler. Bu bağlamda 2008 Finansal Krizi sürecinde özellikle ABD ve İtalya da hükümet yetkililerinin derecelendirme kuruluşlarına yönelttiği eleştiriler öne çıkmaktadır. Bu eleştirilere paralel olarak 2013 yılında ABD Adalet Bakanlığı küresel ekonomide büyük krize neden olan konut kredilerine bağlı varlıklara verdiği notlar nedeniyle S\&P'yi mahkemeye vermiştir. İtalya'nın ise, S\&P'yi ülkenin tarihi ve kültürel zenginliklerini hesaba katmadan notunu düşürdüğü için mahkemeye vermeyi düşündüğü iddia edilmiştir.

Bu yüzden işbu çalışmada kredi notlarının ne kadar gerçek durumu yansıttığı, derecelendirme süreçlerinin şeffaflığı ve güvenilirliği araştırılmıştır.

Kredi derecelendirme kuruluşlarının derecelendirdikleri ülkelere verdikleri kredi notlarına çoğunlukla şüphe ile bakılmış, küresel krizlerin hemen ardından şüpheler ve eleştiriler artmıştır. Yukarıda ifade edildiği üzere italya'da Sayıştay, S\&P'nin ülkenin tarihi ve kültürel özellikleri yok sayılarak kredi notunun düşürülmesiyle piyasaların negatif etkilendiğini ve bu şekilde İtalya'nın 234 milyar avro seviyesinde zarara uğradığını iddia etmiştir. Krizleri öngörme kabiliyetlerinin düşük olduğu kredi derecelendirme kuruluşları, kriz sonrası ani tepkiler vererek ülkelerin notlarını tek seferde birkaç kademe birden düşürmektedir. Düşen kredi notları küresel kriz sebebiyle zaten hassas olan piyasaların daha fazla bozulmasına ve krizin daha yoğun hissedilmesine sebep olmaktadır. Derecelendirme kuruluşlarının en büyük eksikliği, piyasa dengesizliklerini fark edememeleri ve piyasaları oldukça geriden takip etmeleridir. Goldman Sachs Başekonomisti Jim O'Neill da uluslararası kredi derecelendirme kuruluşlarının hantal olduklarını ve piyasaları yavaş hareket geriden takip ettiklerini belirtmiştir. Standard Bank Başekonomisti Timoty Ash ise Türkiye gibi bazı ülkelerin geçmiş performansının uluslararası kredi derecelendirme kuruluşları tarafından yeteri kadar iyi değerlendirilmediğini ifade etmiştir. Örnek olarak bazı ülkelerin düzenli olarak borçlarını ödemesine karşın, bu tarz tutumlara derecelendirme süreçlerinde yeteri kadar ağırlık verilmediğini vurgulamıştır. Fulghieri vd. 2014 yılında yaptıkları çalışmalarında kredi derecelendirme kuruluşları tarafından verilen notların ihraççıların finansman 
maliyetleri açısından önemini vurgulamışlardır. Bu nedenle ilan edilen kredi notlarının derecelendirme kuruluşlar tarafından kendi çıkarları doğrultusunda kullanılabileceğini ileri sürmüşlerdir (Fulghieri, Strobl ve Xia, 2013).

Bu gibi olumsuzluklar sebebiyle, ülke riski hakkında daha güncel bilgiler sağlamak için piyasalarda kredi temerrüt takası primi (CDS) gibi alternatif arayışlar başlamıştır.

CDS primleri, kredi derecelendirme kuruluşlarının 1990'lı yıllardaki Asya krizi ve özellikle 2008 küresel krizinde gösterdikleri düşük performansın ardından yoğun olarak eleştirilmesiyle kredi notlarının alternatifi olarak değerlendirilmiş ve ilgi gösterilmeye başlamıştır. Ülkelerin belirli zaman aralıklarında yapılacak CDS primi karşılaştırmalarında kredi derecelendirme kuruluşlarının verdikleri notların piyasada oluşan risk algısına uygun olup olmadığı ve ülkeler arasında pozitif ya da negatif seçim yapılıp yapılmadığı ölçülebilir (Balıkçıoğlu ve Yılmaz, 2013).

Kredi notlarının etkisinin araştırılması amacıyla Brezilya, Güney Afrika, Hindistan, Meksika, Rusya ve Türkiye'nin aralarında olduğu altı tane gelişmekte olan ülke seçilmiştir. Gelişmiş ekonomilere kıyasla daha fazla uluslararası yatırım ihtiyacı olan ve dış şoklara karşı piyasaları daha hassas olduğu için BRıCS-T ülkeleri çalışmanın analiz kısmına dahil edilmiştir. Bu ülkeler uluslararası finans piyasaları tarafından BRICS-T ülkeleri olarak gruplandırılmaktadır. Normalde BRICS-T ülkeleri arasında yer alan Çin hakkında yeterli ve güvenilir bilgiye ulaşılamadığı için bu çalışmanın kapsamı dışında tutulmuştur. Onun yerine yine önemli bir gelişen ekonomi olan Meksika analiz edilmiştir. Söz konusu ülkelerin makroekonomik verileri, CDS primleri ve bankacılık-finans endeksleri alınarak; notların değişim öncesi ve sonrası değerlendirilmiş, tablo ve grafikler yardımıyla analiz edilmiştir. Bu aşamada kredi notlarının bankacılık sektörüne etkisinin analizini gözlemlemek için; her ülkeden halka açık bankalar seçilmiş, bu bankaların hisse fiyatları ve mali oranlarındaki değişim incelenerek banka ve ülke notu birlikte dikkate alınarak değerlendirilmiştir.

Çalışmanın bundan sonraki yapısı şu şekilde oluşturulmuştur. Illk bölümde konu ile uluslararası ve ulusal literatürde yer alan başlıca çalışmalar incelenmiştir. Daha sonraki bölümde ise analiz çalışması yer almaktadır. Çalışmada incelenen gelişmekte olan ülkelerin, 2005-2017 tarihi aralığındaki uzun vadeli kredi derecelendirme notları, ülkelerin CDS primi ve bankacılık-finans endeksi verileri alınarak grafik yardımıyla analiz edilmiştir. Son bölümde ise yapılan analiz sonucu elde edilen bulgular tartışııış ve sorunun çözümüne yönelik öneriler sunulmuştur.

\section{Literatür Çalışması}

Çalışmada ülke kredi notlarının incelendiği benzer çalışmalar literatür taraması olarak verilmiştir. Kredi derecelendirme işlemi, her ne kadar bir görüş niteliğinde olsa da verilen notların, yatırımcıların yatırım kararları üzerinde ciddi etkileri bulunmaktadır. Yerli ve yabancı yatırımcılar kredi derecelendirme kuruluşlarının ülkelere verdikleri notlardan etkilenmektedir. Cantor ve Packer (1996) kredi derecelendirme kuruluşlarının derecelendirme süreçlerinde dikkat ettikleri faktörleri ve piyasa üzerindeki etkilerini istatistiki yöntemleri kullanarak araştırmışlardır. Derecelendirme süreçlerinin temel makroekonomik faktörler ile uyumlu olduğunu ifade etmişlerdir. Ayrıca başlıca kredi derecelendirme kuruluşları tarafından yapılan derecelendirmenin finans piyasalarında etkili olduğunu belirtmişlerdir. Reisen ve Von Maaltzan (1999), Mellios ve Paget-Blanc (2006) ve Jaramillo ve Tejeda (2011) da yine istatistiki yöntemler yardımıyla kredi derecelendirme süreçlerine etki eden faktörleri araştırmışlar ve genel olarak benzer bulgulara ulaşmışlardır. Bheenick (2005) tarafından yapılan bir araştırmada ise ulaşılan temel bulgu; mevcut ekonomik ve finansal göstergelerin tek başına derecelendirme notunu belirlemeye yetmediği şeklindedir. Hatta derecelendirme sürecinde ekonomik değişkenlerin etkisinin gelişmekte olan ülkeler için gelişmiş ülkelerle aynı olmadığına dair bulgulara ulaşmıştır. Iyengar (2010) ve Williams vd. (2013) yayınladıkları makalelerinde birbiriyle örtüşen şu sonuca ulaşmışlardır: Kredi derecelendirme kuruluşları farklı metodolojiler kullanarak kredi notu açıklamakta ve ülkeler için öznel değerlendirmede bulunmaktadırlar. Gehring ve Fuchs (2017) tarafından yapılan araştırmada elde edilen bulgu; ulusal derecelendirmede ülkeye yönelik önyargının varlığını gösteren bulgular elde edildiği yönündedir. Önyargının küresel mali krizin başlangıcından sonra daha da belirginleştiği sonucuna ulaşılmıştır. Ferri vd. (1999) ve Reisen ve Von Maltzan (1999) kredi derecelendirme kuruluşlarının yaptıkları 
değerlendirmeler ile özellikle gelişmekte olan ülkelerde krizlerin olumsuz etkilerini daha da arttırdıkları ifade etmişlerdir. Kunovac ve Ravnik (2017) tarafından yapılan çalışmada ulaşılan sonuç; derecelendirme kuruluşlarının finansal piyasalara önemli yeni bilgiler açıklamadığı yönündedir. Kredi notlarının yalnızca ülke borçlanma maliyetleri için sınırlı ekonomik öneme sahip olduğu görüşünü savunmaktadırlar. Türkiye'de yapılan çalışmalarda ise Balıkçıoğlu ve Yılmaz (2013) ve Kargi (2014) farklı zamanlarda yayınladıkları makalelerde ülkelerin kredi notlarının makroekonomik değişkenlerden (GSYH, kişi başına düşen milli gelir, ekonomik büyüme, enflasyon, döviz rezervi, dış borç, bütçe açı̆̆ı) etkilendiği sonucuna varmışlardır. Duran ve Küçüksaraç (2017) ise kredi notlarının piyasadaki değişimlere çok yavaş tepki verdiği sonucuna ulaşmıştır.

Remolona vd. (2008) gelişmekte olan ülke riskini etkileyen faktörler üzerine yaptıkları araştırmada CDS primlerine dayalı bir yöntem kullanmışlar ve çalışmanın sonucunda anlamlı bulgulara ulaştıklarını ileri sürmüşlerdir. Pan ve Singleton (2008) Türkiye, Meksika ve Kore üzerine yaptıkları araştırmada CDS primlerini ülke risk priminin tahmin edilmesinde kullanmışlar ve anlamlı bulgulara ulaştıklarını ileri sürmüşlerdir. Aksoylu ve Görmüş (2018) çalışmalarında aralarında Türkiye'nin de olduğu 9 gelişmekte olan ülkeyi incelemişler ve CDS primlerindeki değişmenin ülkeler için seçilen finansal değişkenlerdeki değişimlerle uyumlu olduğu sonucuna ulaşmışlardır. Ersan ve Günay (2009) ise yaptıkları çalışmada Türkiye'nin ülke riskinin ölçülmesinde CDS'leri incelemişlerdir ve CDS primlerinin riskin tahmin edilmesinde kullanılmasının yerinde olacağını belirtmişlerdir. Kalbaska ve Gatkowski (2012) genel olarak Avrupa Birliği ülkeleri ve özel olarak da PiiGS (Portekiz, İrlanda, İtalya, Yunanistan ve İspanya) ülkeleri üzerine yaptığı çalışmada CDS primlerinin kriz döneminde hızlı tepki vererek dalgalanmalarının arttığını ifade etmişlerdir. Stulz (2010) ise yaptığı çalışmada CDS piyasasındaki işlemlerin de yaşanan krizleri derinleştirici etkisi olduğunu ileri sürmüştür.

\section{Veri, Yöntem ve Uygulama}

Çalışmanın uygulama kısmında dünyadaki başlıca gelişen ekonomiler olan; Brezilya, Hindistan, Rusya, Meksika, Güney Afrika ve Türkiye seçilmiştir. Seçilen ülkelerdeki bankacılık ve finans endeksinde yer alan bankaların kredi derecelendirme notlarının değişimleri incelenmiştir. İncelenen yıllar makroekonomik verilerin de ele alındığı 31.12.2005-31.12.2017 dönemini kapsamaktadır. Makroekonomik değişkenler olarak; yılsonu itibarıyla GSYH, kişi başına düşen milli gelir, enflasyon oranı, kamu dış borç miktarı, merkez bankası döviz rezervi, cari işlemler dengesi seçilmiştir.

Çalışmada incelenen gelişmekte olan ülkelerin, 2005-2017 tarihi aralığındaki uzun vadeli kredi derecelendirme notları, ülkelerin CDS primi ve bankacılık-finans endeksi verileri alınarak grafik yardımıyla incelenmeye çalışılmıştır. Illk olarak gelişmekte olan ülkelerin ve bankaların kredi notları tablolarla verilmiş daha sonra her ülke için bankacılık sektörüne etkisinin analizini görmek adına halka açık bankalarının kredi derecelendirme notları, hisse senedi fiyatları yerel para cinsinden alınarak öz sermaye ve aktif karlılığı oranları ile değerlendirilmiş ve grafiklerle yorumlanmıştır. Çalışmada kullanılan tüm veriler Bloomberg veri terminali yardımıyla indirilmiş ve gerekli düzenlemeler yapıldıktan sonra yapılan analizlerde kullanılmıştır.

Borsa endeksi; içerisinde belirli hisse senetlerini bulunduran, bu hisse senetlerinin farklı ağırlıklarla hesaplanması sonucu bulunan bir değerdir. Her hissenin endeks değeri içerisindeki ağırlıkları farklılık göstermektedir. Bankacılık endeksi halka açık bankalardan, finans endeksi halka açık ve ülkenin önemli finansal kuruluşlarından oluşmaktadır.

\subsection{Gelişmekte Olan Ülkelerde Makroekonomik Veriler}

Bir ülkenin ekonomik gücünü anlamak için, bakılması gereken önemli noktalardan biri makro koşullardır. Bu koşullar ne kadar gelişmişse, o ülkenin ekonomisi o kadar gelişmiştir. Finans piyasalarında alım - satım işlemi yapan yatırımcılar için, bu göstergeler önemlidir. Yatırım araçlarının fiyat seviyelerinde meydana gelecek değişimlerin sinyallerinin alınması için özellikle makroekonomik verilerin takip edilmesi gerekiyor. Bunun sebebi, ülke ekonomilerini direkt etkilemeleridir. Bu da yatırımcıların bütçesine etki ettiği gibi, arz ve talep faktörlerinin devreye girmesine neden olur. Böylece enstrümanların değerlerinde hissedilir düşüşler ve yükselişler meydana gelir. Ekonomiyi derinden etkileyen makroekonomik veriler, parasal kaynaklı 
tüm konuları etkiler. Bu yüzden de piyasalarda dalgalanmalar meydana gelir. Genellikle enflasyon, gayri safi yurt içi hasıla, cari açık gibi etkenler, yatırım araçlarının değerinin yükselmesine ve düşmesine neden olan etmenler arasında sayılabilir. Bunun dışında da piyasayı etkileyen olaylar ve gelişmeler vardır. Bunlar; ülkeler arası anlaşmazlıklar, önemli kişilerin ve merkez bankalarının açıklamaları, savaşlar, doğal afetler gibi çoğaltabilecek hususlardır.

\subsection{Kredi Temerrüt Takası (CDS) ile Derecelendirme Arasındaki ilişki}

Kredi derecelendirme kuruluşlarının derecelendirdikleri ülkelere verdikleri kredi notlarına çoğunlukla şüphe ile bakılmış, küresel krizlerin hemen ardından şüpheler ve eleştiriler artmıştır. Krizleri öngörme kabiliyetlerinin düşük olduğu kredi derecelendirme kuruluşları, kriz sonrası ani tepkiler vererek ülkelerin notlarını tek seferde birkaç kademe birden düşürmektedir. Düşen kredi notları küresel kriz sebebiyle zaten hassas olan piyasaların daha fazla bozulmasına ve krizin daha yoğun hissedilmesine sebep olmaktadır. Derecelendirme kuruluşlarının en büyük eksikliği, piyasa dengesizliklerini fark edememeleri ve piyasaları oldukça geriden takip etmeleridir. Bu gibi olumsuzluklar sebebiyle, ülke riski hakkında daha güncel bilgiler sağlamak için piyasalarda kredi temerrüt takası (CDS) gibi alternatif arayışlar başlamıştır.

Kredi temerrüt takası, bir sigorta şirketinin garanti kapsamına aldığı ürünlerin sözleşme dâhilindeki her tür teminatını ödemesi gibi, belli bir bedel karşıı̆ı̆ında, herhangi bir finansal kredinin geri ödenmeme riskine karşı alacaklı tarafın parasını garanti kapsamına alan, bir çeşit finansal sigorta sözleşmesi niteliğinde kredi türev enstrümanıdır.

CDS primleri, kredi derecelendirme kuruluşlarının 1990'lı yıllardaki Asya krizi ve özellikle 2008 küresel krizinde gösterdikleri düşük performansın ardından yoğun olarak eleştirilmesiyle kredi notlarının alternatifi olarak değerlendirilmiş ve ilgi gösterilmeye başlamışıı. Ülkelerin belirli zaman aralıklarında yapılacak CDS primi karşılaştırmalarında kredi derecelendirme kuruluşlarının verdikleri notların piyasada oluşan risk algısına uygun olup olmadığı ve ülkeler arasında pozitif ya da negatif seçim yapılıp yapıımadığı ölçülebilir (Ulusoy ve Yılmaz, 2017).

CDS primleri rakamsal ifadelerdir. Ülkenin risk priminin artması, ülkenin temerrüde düşme olasılığının arttığının göstergesidir. Bu primler kredi notlarının aksine gayet hareketli, dinamik piyasa koşulları altında oluşabilecek ekonomik, sosyal ve politik değişkenlere daha hassas ve anında tepki gösterir rakamlardır. CDS'ler ülkeye ilişkin piyasa algısını daha hassas yansıtmaktadır. Kredi derecelendirme kuruluşları notlarını harf cinsinden açıkladıklarından benzer nota sahip birden fazla ülke olabilmektedir. Bu durum aynı nota sahip ülkelerin ekonomik şartlarının veya taşıdıkları riskin aynı düzeyde olduğu anlamına gelmez. Buna karşılık CDS primleri rakamsal ifadeler olduklarından ve bu rakamlar küsuratlar halinde bile değişiklik gösterebildiğinden, aynı nota sahip ülkelerin arasında daha gerçekçi bir kıyas yapma imkanı sunmaktadır (Ulusoy ve Yılmaz, 2017).

\subsection{Brezilya}

Çalışmada Brezilya Finans Endeksi verileri USD cinsinden alınarak aylık ve yıllık değişimleri incelenmiştir. Ülkenin uzun vadeli kredi notunun finans sektörüne genel etkisinin analizi için Brezilya Finans Sektörü endeksi kullanıımıştır. Brezilya Finans Endeksi: Brezilya piyasasındaki finans sektörü hisselerinin performansının ölçülmesi için oluşturulmuştur. Endeksi oluşturan şirketler piyasa değerine göre ağırlıklandırılmak suretiyle endekse dâhil edilmiştir.

Grafik 1'de Brezilya Finans Endeksi ve CDS primi verileri 2005-2017 aralığında aylık olarak alınarak, derecelendirme kuruluşları tarafından verilen uzun vadeli kredi notu değişimlerinin bankacılık endeksine etkileri analiz edilmeye çalısııımış ve CDS priminin kredi notundan önce ve sonraki hareketleri izlenerek piyasadaki olaylara verdiği tepkiler notlarla karşılaştırılmıştır. 
Grafik 1. Brezilya Finans Endeksi ve CDS Primi (USD)*

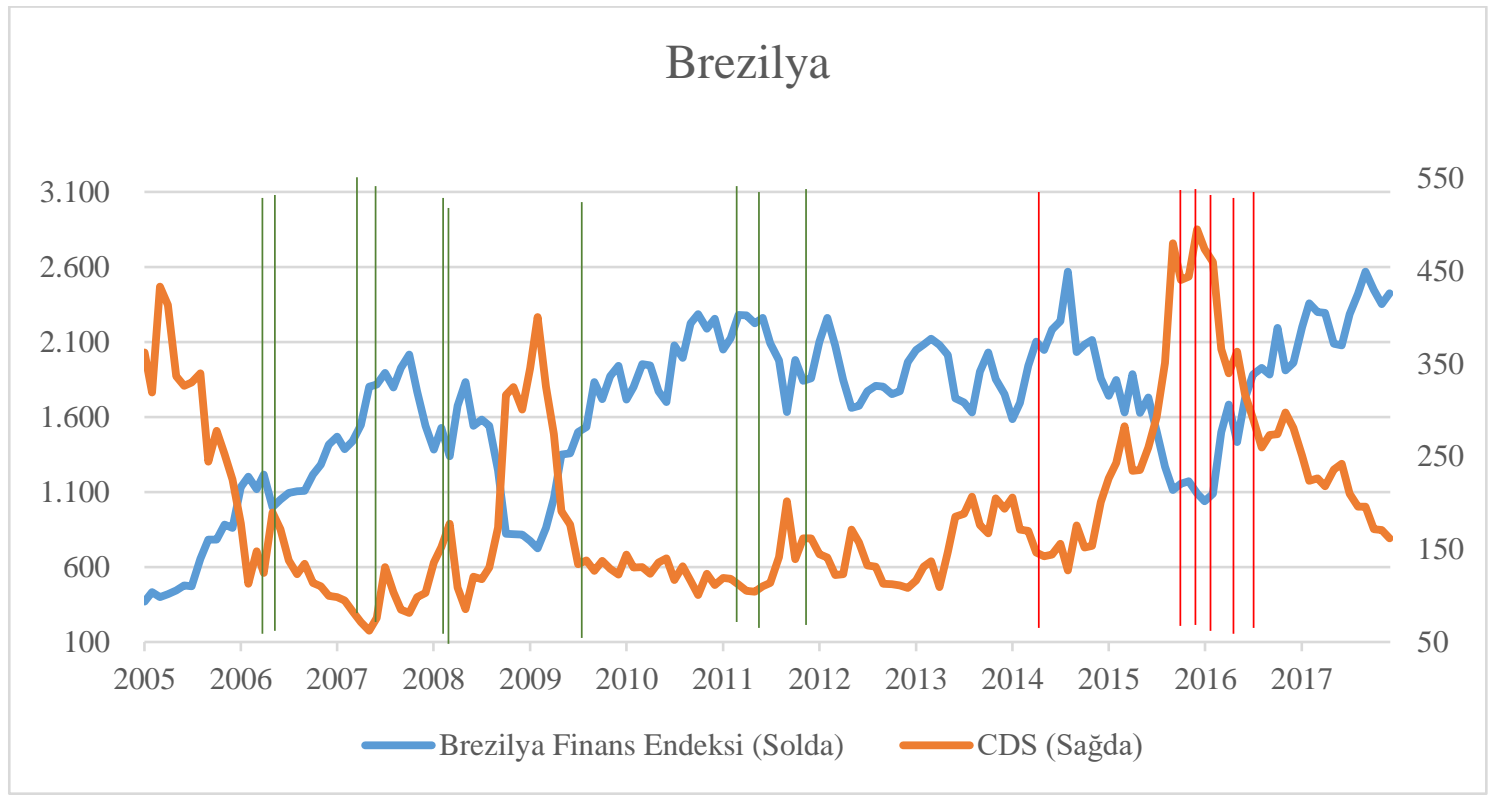

Kaynak: Bloomberg veri terminalinden sağlanan verilerle yazarlar tarafından oluşturulmuştur (05/07/2018).

* Grafikte yer alan dikey çizgiler not değişimlerinin gerçekleştiği tarihleri göstermektedir. Yeşille gösterilen dikey çizgiler not artışını ifade ederken, kırmızıyla gösterilen dikey çizgiler not düşüşünü ifade etmektedir

Brezilya'nın 2005-2017 yılları arasında aldığı kredi notlarına baktığımızda çalışmada ele alınan diğer ülkelere göre daha çok not değişimi yaşandığı gözlenmektedir. 2006 yılı Haziran ayında Fitch ülke kredi notu BB-'den BB'ye yükseltmiştir. Ağustos ayında ise Moody's Ba3'ten Ba2'ye yükseltmiş̧ir. 2007 yılı Mayıs ayında S\&P ve Fitch ülke notunu BB'den BB+'ya, Moody's ise yine aynı ayda kredi notunu Ba2 seviyesinde teyit etmiş Ağustos ayında ise Ba1'e yükseltmiştir. 2008 yılının Nisan ayında S\&P Mayıs ayında da Fitch ülke notunu BBB'ye yükseltmiştir. 2009 yılının Temmuz ayında Moody's Ba1 seviyesindeki notu teyit etmiş, Eylül ayında ise bir basamak arttırarak Baa3 ile yatııım yapılabilir seviyeye getirmiştir. 2007 ile 2010 yılları arasında küresel ekonomik kriz ve CDS primindeki artışa rağmen üç büyük kredi derecelendirme kuruluşunca ülkenin spekülatif seviyedeki notunun yatırım yapılabilir seviyeye çıkarılması dikkat çekmektedir. Grafikte aynı tarih aralı̆ıında CDS priminin yükselmesiyle ülkenin bankacılık endeksinde de sert düşüş yaşandığı görülmektedir. Çalışmanın üçüncü bölümünde verilen makroekonomik verilerde de not artışı yapılan ilgili yıllarda büyük bir olumlu gelişme görülmemiştir.

2011 yılında not artışları devam etmiştir. Illk olarak Nisan ayında Fitch, Kasım ayında da S\&P ülke notunu BBB seviyesine yükseltmiştir. Haziran ayında Moody's de ülke notunu bir kademe arttırarak Baa2'ye taşımıştır. 2014 yılı Mart ayında ilk not indirimi S\&P tarafından yapılıyor ve ülke notu BBB-'ye düşürülüyor. 2015 yılı Ağustos ayında Moody's ülke notunu Baa3'e indirmiştir. Eylül ayında S\&P ise BB+ notuyla ülke notunu spekülatif seviyeye çekmiştir. S\&P, Brezilya'nın notunun spekülatif seviyeye düşürülmesine neden olarak ülkedeki siyasi ve ekonomik sorunların, mali politikaların uygulanmasını zorlaştırdığını vurgulayarak, ekonomik daralma sürecinin bu nedenlerle uzadığı görüşüne yer vermiştir. Fitch de ilk olarak Ekim ayında BBB-'ye Aralık ayında BB+'ya düşürerek ülke notunu spekülatif seviyeye çeken ikinci derecelendirme kuruluşu olmuştur. Fitch, ülke notunun spekülatif seviyeye düşürülmesine gerekçe olarak kötüleşen ekonomik görünüm ve artan siyasi riskleri göstererek not düşüşünün ekonominin beklentilerden daha derin bir resesyonda olmasını ve hükümetin mali önlemleri etkin biçimde uygulama kapasitesini sarsan siyasi belirsizliklerin artmasını yansıttığını belirtmiştir.

Üçüncü bölümde incelenen makroekonomik verilerde değinilen 2015 yılı Ağustos ayında petrol fiyatlarının \%20'nin üzerinde düşüş kaydederek varil başına 41 USD seviyesine kadar düşmesiyle Rusya'da da 
gözlemlenen bozulmaya paralel Brezilya'da enflasyon oranında artış, GSYH ve kişi başına düşen milli gelir rakamında belirgin bir düşüş kaydedilmiştir.

2016 yılı Şubat ayında Moody's Baa3 olan ülke notunu iki kademe birden düşürerek Ba2 olarak açıklamıştır. Moody's not indirimine neden olarak düşük büyüme ortamında Brezilya'nın borç değerlerinde görünümün daha da kötüleşmesini göstermiştir. Ardından Mayıs ayında Fitch bir kademe daha not indirimine gitmiş ve ülke notunu BB olarak açıklamıştır. 2017 yılında not yayınlayan tek derecelendirme kuruluşu S\&P olmuştur. 2016 yılında açıkladığı BB seviyesindeki ülke notunu 2017 yılı Mayıs ve Ağustos ayında teyit etmiştir.

Grafikte dikkat çeken bir diğer tarih aralığı 2015 ile 2017 arasında yapılan not indirimleridir. Bu dönemde ülkenin uzun vadeli kredi notu üç derecelendirme kuruluşunca da spekülatif seviyeye indirilmiştir. Not indirimlerinin CDS primlerinin zirve yaptığı noktada yapılması bize kredi derecelendirme kuruluşlarının piyasayı takipte geciktiklerini göstermektedir. Oligopol durumdaki kredi derecelendirme kuruluşlarının önceden önlem alınmasına imkan tanıyacak güncel bilgi arzı konusunda çok hassas olamadığı görülmektedir.

Aynı zamanda ekonomik kriz içinde bulunan bir ülkenin derecelendirme kuruluşlarınca not indirimi tepkisiyle karşılaşması, zaten hassas olan piyasaların daha fevri tepkiler vermesine ve koşulların daha da bozulmasına neden olmaktadır. Kriz nedeniyle aşırı kırılgan olan piyasaların not indirimi ile kırılganlığı artmakta ve birbirini tetikleyen sistemik krizlere yol açmaktadır.(Akçayır, 2013)

\subsection{Güney Afrika}

Çalışmada FTSE/JSE (Financial Times Stock Exchange/Joint Stock Company) Afrika Bankacılık Endeksi verileri USD cinsinden alınarak aylık ve yıllık değişimleri incelenmiştir. FTSE/JSE Afrika Bankacılık Endeksi: Güney Afrika bankalarının piyasa değerleri ağırlıklandırılmak suretiyle oluşturulmuş bir endekstir. Ülkedeki başlıca banka ve finans kuruluşları endekse dahildir.

Güney Afrika'nın beş yıllık ülke CDS primi ve FTSE/JSE Afrika Bankacılık Endeksi'nin (USD cinsinden) hareketi ile kredi derecelendirme notlarının yıllar itibariyle gösterdiği değişim Grafik 2 yardımıyla anlatılmıştır.

Grafik 2. Güney Afrika FTSE/JSE Bankacılık Endeksi ve CDS Primi (USD)*

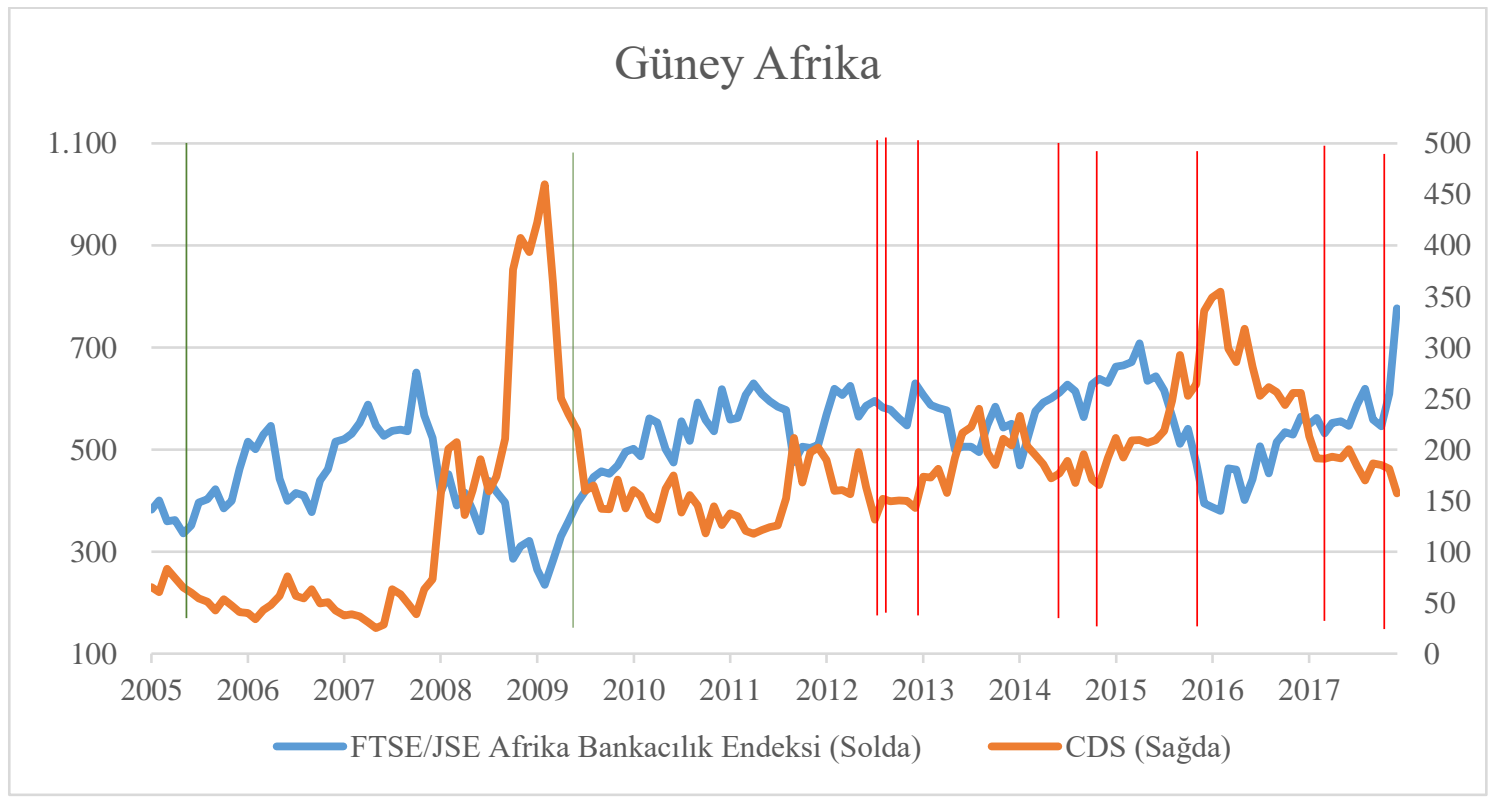

Kaynak: Bloomberg veri terminalinden sağlanan verilerle yazarlar tarafından oluşturulmuştur (04/08/2018).

* Grafikte yer alan dikey çizgiler not değişimlerinin gerçekleştiği tarihleri göstermektedir. Yeşille gösterilen dikey çizgiler not artışını ifade ederken, kırmızıyla gösterilen dikey çizgiler not düşüşünü ifade etmektedir. 
Grafik 2'de FTSE/JSE Afrika Bankacılık Endeksi ve CDS primi verileri 2005-2017 aralığında aylık olarak alınarak, derecelendirme kuruluşları tarafından verilen uzun vadeli kredi notu değişimlerinin bankacılık endeksine etkileri analiz edilmeye çalışılmış ve CDS priminin kredi notundan önce ve sonraki hareketleri izlenerek piyasadaki olaylara verdiği tepkiler notlarla karşılaştırılmıştır.

Çalışmada ele alınan 2005-2017 yılları arasında ilk olarak 2005 yılında her üç derecelendirme kuruluşu da ülkenin uzun vadeli kredi notunu yatırım yapılabilir seviyede açıklamıştır. Moody's tarafından 2009 yılı Temmuz ayında ülkenin kredi notu A3'e yükseltilmiştir. Bir önceki kredi notunu 2005 yılının Ocak ayında Baa1 olarak açıklayan kuruluş ülkenin kredi notunu bir basamak arttırmıştır. Moody's küresel krizin hemen ardından diğer kredi derecelendirme kuruluşları not güncellemesine gitmezken yaptığı not artışını 2012 yılı Eylül ayında yaptığı not indirimiyle eski seviyesine getirmiştir. Her iki not değişikliğinde ülke CDS primi neredeyse aynı değerlerdeyken not indirimi yaptığı 2012 yılı Eylül ayında bankacılık endeksinde 2009 yılı verisine göre artış yaşandığı görülmektedir. Not düşüşünün yaşandığı dönemde grafikte de görüldüğü şekilde CDS priminde ciddi bir hareket gözlenmemektedir. S\&P 2012 yılı Ekim ayında ülkenin uzun vadeli kredi notunu BBB'ye indirmiştir. Fitch de 2013 yılı Ocak ayında ülkenin kredi notunu BBB seviyesine çekmiştir. Ardından 2014 yılında Moody's bir not indirimine daha giderek kredi notunu Baa2, S\&P da BBB- olarak açıklamıştır. 2015 yılının son ayında Fitch'ten gelen not indirimiyle ülke notu BBB- olarak değerlendirilmiştir. Yine ilgili dönemde bankacılık endeksinde yükseliş trendi görülmektedir.

2016 yılında Moody's ülkenin Baa2 seviyesindeki notunu teyit etmiş ve Mart ayında negatif görünüm açıklarken Mayıs ayında görünümü nötr bırakmıştır. Diğer derecelendirme kuruluşlarından not açıklaması gelmemiştir. Üçüncü bölümde incelenen 2016 yılı makroekonomik verilerinde GSYH'deki düşüş ve dış borç / GSYH oranındaki artış ekonominin bozulduğuna işaret etse de 2016 yılında derecelendirme kuruluşlarınca herhangi bir not güncellemesi yapılmamıştır.

2017 yılı Nisan ayında S\&P ve Fitch'in ülke notunu spekülatif seviye olan BB+'ya düşürürken ülkenin CDS primindeki düşüşün 2017 yılı Ocak ayından itibaren süregeldiği gözlemlenmektedir. Kredi derecelendirme kuruluşlarının piyasayı geriden takip etmeleri ve gerçekleşen olaylar üzerinden notları revize etmeleri nedeniyle CDS primlerinin ülkenin risk durumunu daha iyi yansıttığı kanısı güçlenmektedir. Aynı zamanda grafikte gösterilen bankacılık endeksinde de kredi notu değişiminin etkisinin nötr olduğu görülmektedir. Reyting notu çoğu kez ya geç kalmış ya da erken belirlemelerin izlerini taşıyabiliyor fakat CDS primi her an yeniden arz ve talebe göre belirlendiği için piyasanın anlık reaksiyonunu yansıtmaktadır (Eğilmez, 2016). CDS primlerinin ülke piyasalarını analiz etmede daha bağımsız ve tutarlı oldukları, özellikleri dolayısıyla da kredi notlarından daha avantajı bir yapıya sahip oldukları söylenebilir. Kredi derecelendirme kuruluşlarının piyasadaki dalgalanmaları geç fark etmeleri, olacak olana göre değil olana göre not verdikleri eleştirisini de beraberinde getirmektedir. Bu husus derecelendirme faaliyetleri için tanımlanan "geleceğe ilişkin yapılan tahminlerdir" ibaresiyle çelişmektedir (Ulusoy ve Yılmaz, 2017).

Fitch, Güney Afrika'nın notunun spekülatif seviyeye düşürülmesine neden olarak aralarında kabinede büyük değişikliğe gidilmesinin de yer aldığı siyasi gelişmeleri işaret ederek, bu gelişmelerin yönetişim ve kamu finansmanı standartlarını zayıflattığını gerekçe göstermiştir. Maliye bakanının da değişikliğini kapsayan kabine değişikliğinde ekonomi politikasının yönünde de bir değişim olacağı görüşünün not kararında etkili olduğu ifade edilmiştir. S\&P, ülke notunun spekülatif seviyeye düşürülmesine gerekçe olarak maliye bakanının görevden alınmasının ardından ülkenin benimseyeceği ekonomik ve mali politikaların tahrip edici olacağını göstermiştir. S\&P ve Fitch'in not indirimlerinin ardından Moody's de ülkenin kredi notunu bir süre izlemeye aldıktan sonra Baa2'den Baa3'e indirmiştir. Bu not indirimiyle Güney Afrika, Moody's tarafından yapılan değerlendirme sonucu kredi notu görünümünde yatırım yapılabilir seviyenin en alt basamağında kalmıştır.

2017 yılı Nisan ayında derecelendirme kuruluşlarının kredi notunu düşürme sebebi tamamen siyasi bir gerekçeye dayanmaktadır. Derecelendirme kuruluşları tarafından yapılan not indirimine rağmen CDS priminde düşüş gözlemmiş bankacılık endeksinde ise artış yaşanmıştır. 2017 yılsonunda S\&P bir kademe daha not indirimine giderek ülke notunu BB'ye düşürmüş Moody's de aynı tarihte Haziran ayında açıkladığı Baa3 seviyesindeki notu teyit etmiş fakat görünümü negatif olarak açıklamıştır. 


\subsection{Hindistan}

Çalışmada Nifty Bankacılık Endeksi verileri USD cinsinden alınarak aylık ve yıllık değişimleri incelenmiştir. Nifty Bankacılık Endeksi: Hindistan'ın bankacılık sektörünün performansının ölçülmesi için oluşturulmuştur. Endeksi oluşturan şirketler piyasa değerine ve işlem hacmine göre ağırlıklandırmak suretiyle endekse dâhil edilmiştir.

Grafik 3. Hindistan Nifty Bankacılık Endeksi ve Beş Yıllık Tahvil Faizi (USD)*

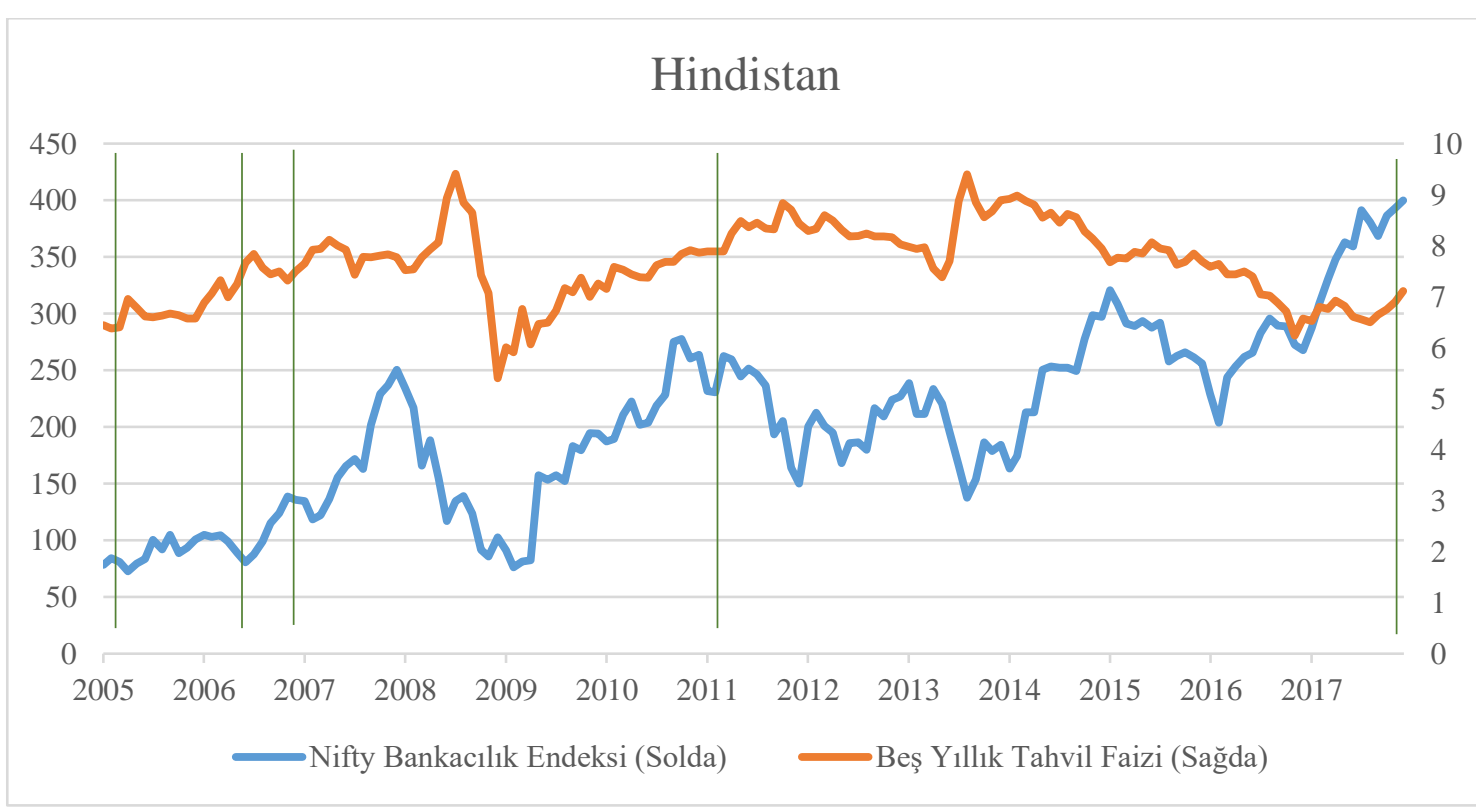

Kaynak: Bloomberg veri terminalinden sağlanan verilerle tarafımca oluşturulmuştur (13/07/2018).

* Grafikte yer alan dikey çizgiler not değişimlerinin gerçekleştiği tarihleri göstermektedir. Yeşille gösterilen dikey çizgiler not artışını ifade etmektedir. Hindistan'ın CDS primi verileri mevcut olmadığından çalışmada bankacılık endeksiyle ülkenin beş yıllık tahvil faizi karşılaştırılmıştır.

Hindistan'ın beş yıllık tahvil faizi ve Nifty Bankacılık Endeksi'nin (USD cinsinden) hareketi ile kredi derecelendirme notlarının yıllar itibariyle gösterdiği değişim Grafik 3 yardımıyla anlatıımıştır.

Hindistan'ın grafiğini incelediğimizde not değişiminin çok sık yaşanmadığını görüyoruz. Illk olarak 2005 yıında S\&P tarafından ülkenin uzun vadeli kredi notunun BB+ olarak açıklandığını görüyoruz. 2006 yılında Fitch tarafından çalışmada ele alınan yıllar itibariyle açıklanan tek not olan BBB-'yi görülmektedir.

2007 yılında S\&P tarafından ülkenin uzun vadeli kredi notunun spekülatif seviyeden BBB- ile yatırım yapılabilir seviyeye yükseltildiğini görüyoruz. Bu not artışına gerekçe olarak Hindistan ekonomisin orta dönemde $\% 7,5$ büyüme eğilimi ile birlikte gücünü ve derece derece büyümesini sürdürmesinin beklendiği ifade edilmiştir. 2008 yılındaki küresel krizde tahvil faizlerindeki artış ve bankacılık endeksindeki düşüş dikkat çekmesine rağmen derecelendirme kuruluşlarınca herhangi bir not değişimine gidilmemiştir. 2009 ve 2010 yılında ülkenin uzun vadeli kredi notunda herhangi bir güncelleme yapılmamıştır. 2011 yılında S\&P ülkenin uzun vadeli kredi notunu 2007 yılında açıklamış olduğu BBB- ile teyit etmiştir. Takip eden yıllarda not değişikliği yaşanmayan ülkede Moody's tarafından çalışmada ele alınan yıllar itibariyle 2017 yılında açıkladığı tek not olan Baa2'yi görüyoruz. Bu kredi notuyla üç derecelendirme kuruluşunca da ülkenin uzun vadeli kredi notu yatırım yapılabilir seviyede değerlendirilmiştir.

Üçüncü bölümde incelediğimiz sayısal verilerde en dikkat çeken makro, GSYH'nin her yıl artış göstermesi ve buna bağlı olarak kişi başına düşen milli gelirin de aynı paralelde ilerlemesidir. Hindistan'ın enflasyon rakamındaki belirgin düşüş, dış borç / GSYH'ye oranı çalışmada ele alınan diğer ülkelere göre oldukça iyi bir performans göstermiştir. 2017 verisinde döviz rezervinde yüksek bir artış gözlenmektedir. Cari açığı da bulunmayan Hindistan makroekonomik veriler açısından olumlu bir grafik çizmektedir. Cari dengeyi 
çalışmada ele alınan yıllar boyunca da koruduğunu üçüncü bölümde incelenen makroekonomik verilerde gözlemledik. Buna rağmen ülkenin uzun vadeli kredi notunda Moody's dışında diğer derecelendirme kuruluşları uzun süredir güncellemeye gitmemiştir.

\subsection{Meksika}

Çalışmada Meksika S\&P/BMV (S\&P/Bolsa Mexicana de Valores) Finans Endeksi verileri USD cinsinden alınarak aylık ve yıllık değişimleri incelenmiştir. S\&P/BMV Finans Endeksi: Meksika piyasasındaki finans sektörünün performansının ölçülmesi için oluşturulmuştur. Endeksi oluşturan şirketler piyasa değerine göre ağırlıklandırımak suretiyle endekse dâhil edilmiştir.

Meksika'nın beş yıllık ülke CDS primi ve S\&P/BMV Finans Endeksi'nin (USD cinsinden) hareketi ile kredi derecelendirme notlarının yıllar itibariyle gösterdiği değişim Grafik 4 yardımıyla anlatılmıştır.

Grafik 4. Meksika S\&P/BMV Finans Endeksi ve CDS Primi (USD)*

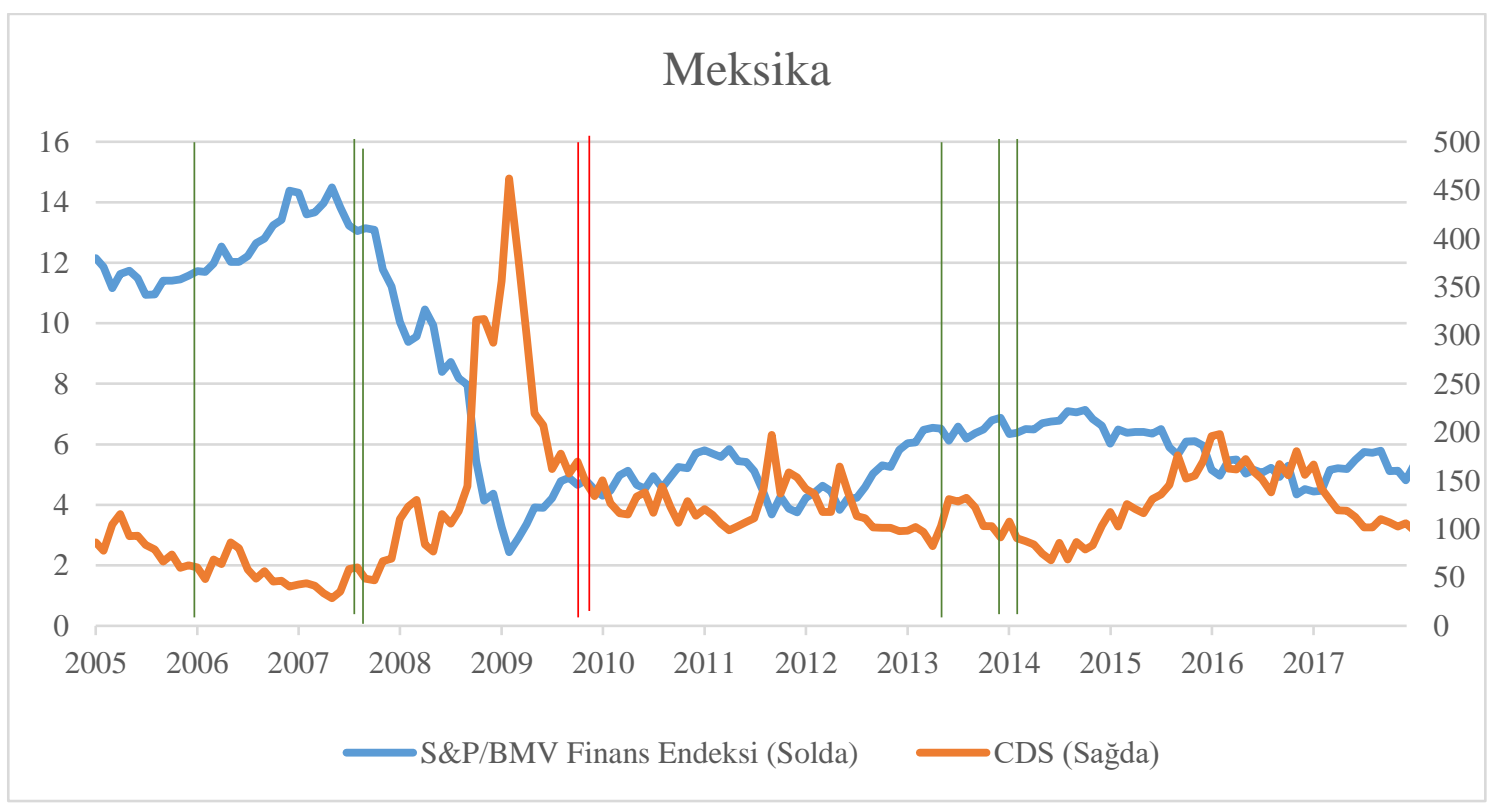

Kaynak: Bloomberg veri terminalinden sağlanan verilerle yazarlar tarafından oluşturulmuştur (15/06/2018).

*: Grafikte yer alan dikey çizgiler not değişimlerinin gerçekleştiği tarihleri göstermektedir. Yeşille gösterilen dikey çizgiler not artışını ifade ederken, kırmızıyla gösterilen dikey çizgiler not düşüşünü ifade etmektedir.

Meksika'nın CDS primi ve finans endeksinde 2005-2017 yıllarını kapsayan grafiğine baktığımızda ilk olarak 2005 yılında ülkenin uzun vadeli kredi notunun S\&P ve Fitch tarafından BBB olarak, Moody's tarafından Baa1 olarak açıklandığını görüyoruz. 2006 yılında herhangi bir not değişimi yaşanmazken 2007 yılının Eylül ve Ekim ayında yine S\&P ve Fitch not artışına gitmiş ve birer kademe arttırarak ülke notunu BBB+ olarak açıklamıştır. 2009 yılında krizin etkisiyle CDS primi 462 puanla en yüksek seviyesini görüyor ve aynı dönemde ülkenin finans endeksi de çalışmada ele alınan yıllar itibariyle en düşük seviyesini görmüştür. Küresel krizin ardından CDS priminin 2008 yılı Mayıs ayından beri süren yükselişine rağmen S\&P ve Fitch'ten kredi notu indirimi 2009 yılsonunda gelmiştir. S\&P ve Fitch ülkenin uzun vadeli kredi notunu BBB seviyesine indirmiştir. S\&P 2009 yılındaki indirime gerekçe olarak kamu maliyesinde karşılaşılan zorlukların son vergi artırımlarına rağmen, gelecek yıllarda da devam edecek olmasını göstermiştir.

Meksika'nın son zamanlarda petrol dışındaki gelirlerini artırmak ve ekonominin verimli çalışması için aldığı tedbirlerin zayıflayan mali profili telafi etmek için yeterli olmayacağını da not indirimine gerekçe olarak eklemiştir.

Finansal veya ekonomik sorun yaşayan bir ülkenin not indiriminin hemen ardından sorunlarının daha da artması derecelendirme kuruluşlarının sistemik açıdan krizi tetiklediği ve derinleştirdiği düşülmektedir 
(Gültekin-Karakaş, Hisarcıklılar, ve Öztürk, 2011). Illerleyen yıllarda 2010-2011 ve 2012'de her üç derecelendirme kuruluşu da ülke notunda değişikliğe gitmemiştir.

2013 yılında yapılan not güncellemelerine baktığımızda ilk olarak Mayıs ayında ülke notunun Fitch tarafından Aralık ayında ise S\&P tarafından BBB+'ya yükseltildiğini görüyoruz. Not artışlarını takiben 2014 yılı Şubat ayında Moody's de kredi notunu A3'e yükseltmiştir. Moody's Meksika'nın kredi notunu A3'e yükseltme sebebi olarak ülkede 2013 yılında onaylanan yapısal reformlarla birlikte büyüme potansiyelinin ve mali temellerinin güçlenmesini göstermiştir. Kapsamlı reform paketinin muhtemel sonucu olacak yüksek büyüme potansiyeliyle birlikte orta vadeli ekonomik beklentilerin iyileştirilmesi de not yükselişine gösterilen sebep olarak açıklanmıştır.

Üçüncü bölümde ele alınan makroekonomik verileri hatırlayacak olursak 2013-2014 yılında yapılan kredi notundaki artışlardan sonra GSYH'de ve kişi başına düşen milli gelirde ilerleyen yıllarda düşüş yaşanmasına rağmen kredi notunda herhangi bir güncelleme gerçekleştirilmediği görülüyor. 2016 yılında da CDS priminde yükseliş gözlemleniyor. CDS priminin piyasadaki verilere ve gerçekleşmelere daha hızlı tepki verdiği ve doğru bilgiyi yansıttığı yorumunu Meksika'nın uzun vadeli notlarını inceleyerek tekrarlayabiliriz. 2017 yılı makroekonomik verilerinde Meksika'nın enflasyon oranında bir önceki yıla göre iki katı bir artış yaşandığı gözlemlenmiştir. Dış borç miktarındaki artışa rağmen GSYH'de kayda değer bir artış yaşanmadığı için dış borç / GSYH oranında da artış yaşanmıştır. Makroekonomik verilerdeki bozulmalara rağmen kredi derecelendirme kuruluşlarınca herhangi bir not güncellemesine gidilmemiştir. Ülkenin kredi notu 2005-2017 yılları arasında üç derecelendirme kuruluşunca da yatırım yapılabilir seviyede kalmıştır.

\subsection{Rusya}

Çalışmada MSCI (Morgan Stanley Capital International) Rusya Finans Endeksi verileri USD cinsinden alınarak aylık ve yıllık değişimleri incelenmiştir. $\mathrm{MSCl}$ Rusya Finans Endeksi: Rusya piyasasında finans sektörünün performansının ölçülmesi için oluşturulmuştur. Endeksi oluşturan şirketler piyasa değerine göre ağırlıklandırılmak suretiyle endekse dâhil edilmiştir. Rusya'nın beş yıllık ülke CDS primi ve MSCI Rusya Finans Endeksi'nin (USD cinsinden) hareketi ile kredi derecelendirme notlarının yıllar itibariyle gösterdiği değişim Grafik 5 yardımıyla anlatılmıştır.

Grafik 5. MSCl Rusya Finans Endeksi ve CDS Primi (USD)*

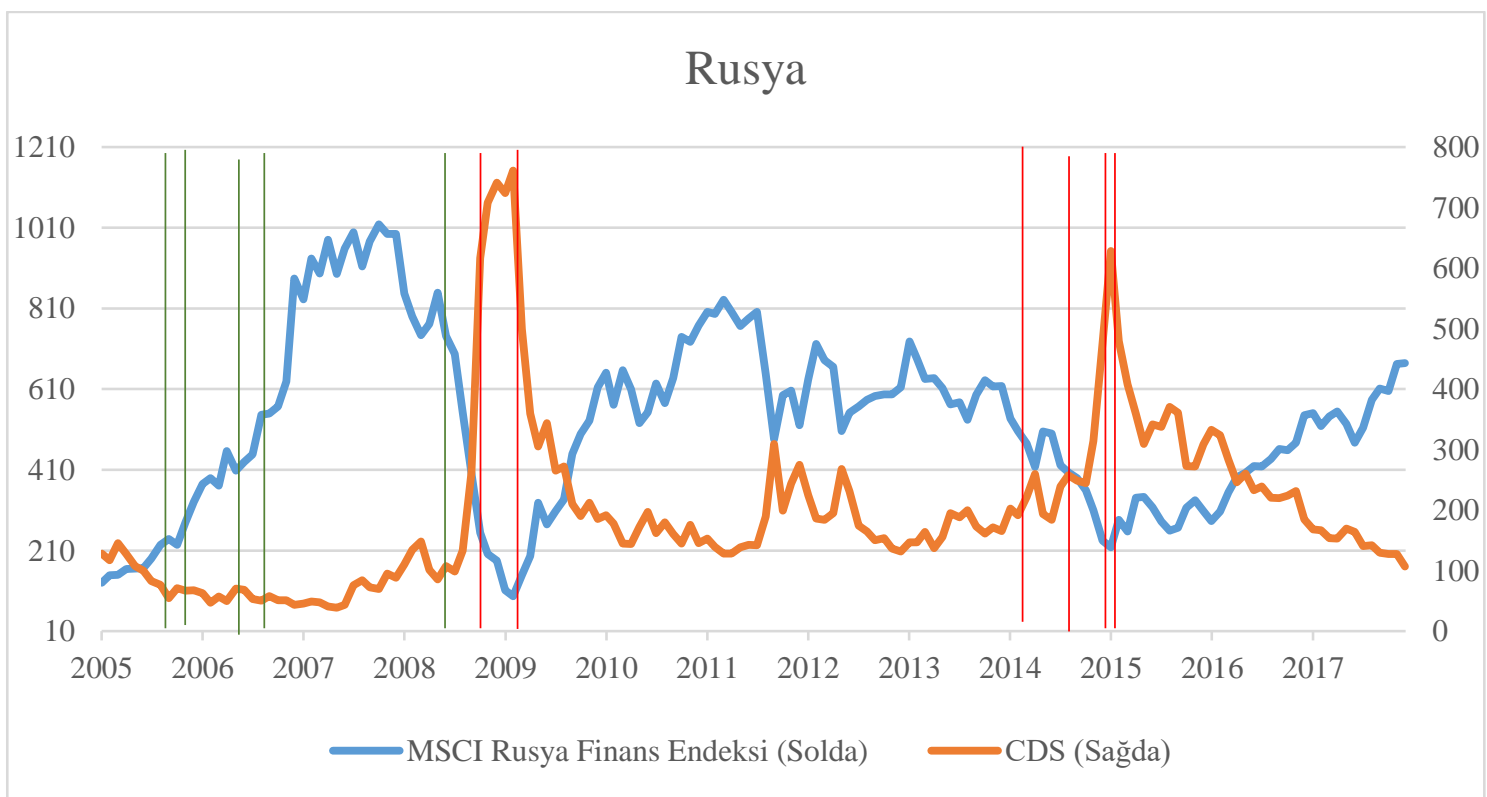

Kaynak: Bloomberg veri terminalinden sağlanan verilerle yazarlar tarafından oluşturulmuştur (15/07/2018).

* Grafikte yer alan dikey çizgiler not değişimlerinin gerçekleştiği tarihleri göstermektedir. Yeşille gösterilen dikey çizgiler not artışını ifade ederken, kırmızıyla gösterilen dikey çizgiler not düşüşünü ifade etmektedir. 
Rusya'nın 2005-2017 yılları arasında aldığı uzun vadeli kredi notları incelendiğinde ilk olarak 2005 yılı Ekim ayında Moody's tarafından uzun vadeli kredi notunun Baa2'ye yükseltildiği sonrasında Aralık ayında da S\&P tarafından BBB seviyesine çıkartıldığı görülüyor. Not artışının yaşandığı 2005 yılında finans endeksinin de yükseliş trendinde olduğu gözlemlenmektedir. Çalışmada ele alınan yıllar itibariyle 2005-2008 yılının ortalarına kadar ülkenin bankacılık endeksinde en yüksek seviye görülürken CDS priminde de en düşük rakamlar gözlemlenmiştir. 2006 yılı Temmuz ayında Fitch, Eylül ayında ise S\&P tarafından ülkenin uzun vadeli kredi notu BBB+'ya yükseltilmiştir. 2008 yılının Temmuz ayında Moody's de ülkenin kredi notunu bir basamak arttırmış ve Baa1'e yükseltmiştir. Not artışının hemen ardından CDS primindeki yükseliş ve finans endeksindeki büyük düşüş dikkat çekmektedir. Küresel krizin de etkisiyle CDS primi rekor seviyeye çıkmıştır. CDS primi 760 civarında olan Rusya iki derecelendirme kuruluşunca da yatırım yapılabilir seviyede görülmüştür.

2008 yılı Aralık ayına geldiğimizde S\&P tarafından ülke notunun BBB'ye indirildiği görülüyor. S\&P not indirimine ülkenin döviz rezervlerinin azalmasını gerekçe göstermiştir. Çalışmanın üçüncü bölümünde ele aldığımız ülkelerin makroekonomik verilerinde 2008 yılsonu rakamlarında bozulmalar görülmüştü. Küresel krizin etkisiyle düşen GSYH, artan dış borç rakamları dikkat çekmiş fakat ilerleyen yıllarda; 2011, 2012 ve 2013'te not indirimine gerekçe gösterilen döviz rezervinde iyileşme görülmesine rağmen derecelendirme kuruluşlarınca herhangi bir olumlu not güncellemesine gidilmemiştir. 2009 yılı Şubat ayında Fitch de ülkenin kredi notunu BBB'ye indirmiştir.

Kredi derecelendirme kuruluşlarına yönlendirilen bir başka eleştiri de; bazı risk faktörlerinin artması gerekçe gösterilerek kredi notları düşürülen ülke ya da bankların, riske neden olan etkenlerin ortadan kalkmasına ve ekonomik konjonktürün iyiye gitmesine rağmen not artırımı konusunda çok yavaş ve isteksiz davrandığı görüşüdür. Herhangi bir kriz belirtisinde kredi notlarını aniden birkaç basamak düşüren derecelendirme kuruluşları not artıımı konusunda aynı hız ve istekliliği göstermemektedir (Akçayır, 2013).

2010-2011-2012 ve 2013 yılında her üç derecelendirme kuruluşu da not güncellemesine gitmemiştir. 2014 yılında S\&P Nisan ayında ülke notunu BBB-'ye indirmiş Aralık ayında da notunu teyit etmiş ve görünümünü negatif olarak açıklamıştır. Moody's ilk olarak Mart ayında bankanın Baa1 seviyesindeki notunu teyit etmiş fakat görünümünü negatif olarak açıklamış ve Ekim ayında notu Baa2 seviyesine indirmiştir. Not indiriminin yapıldığı dönemdeki CDS primi ve finans endeksi verilerine baktığımızda not değişimi yapılmayan 2011 yılındaki seviyeler görülmektedir. Not indirimlerini 2015 yılı Ocak ayında gelen yeni not düşüşleri takip etmiştir. Moody's Ocak ayında önce Baa3 seviyesine indirdiği notu negatif görünümde açıklamış ardından Şubat ayında ise ülke notunu Ba1'e çekerek spekülatif seviyeye indirmiştir. S\&P da Ocak ayında BB+ olarak açıkladığı notla ülkenin uzun vadeli kredi notunu spekülatif seviyeye indiren derecelendirme kuruluşlarından olmuştur. Aynı ay içerisinde Fitch de ülke notunu bir basamak indirmiş ve BBB- olarak açıklamıştır. 2015 yılında ülke CDS priminin en yüksek olduğu seviyede gelen not indirimi ilerleyen yıllarda CDS primi düştügünde ve makroekonomik veriler; GSYH, döviz rezervi ve cari denge gibi rakamlarda iyileşme görülmesine rağmen güncellenmemiştir. Moody's 2016 yılında ülkenin kredi notunu Ba1 olarak teyit etmiş görünüm yine negatif olarak açıklanmıştır. 2017 yılında derecelendirme kuruluşlarınca ülke notunda güncelleme yapılmamıştır.

\subsection{Türkiye}

Çalışmada BIST (Borsa İstanbul) Bankacılık Endeksi verileri USD cinsinden alınarak aylık ve yıllık değişimleri incelenmiştir. BIST Bankacılık Endeksi: Türkiye piyasasındaki bankaların performansının ölçülmesi için oluşturulmuştur. Endeksi oluşturan şirketler piyasa değerine göre ağırlıklandırmak suretiyle endekse dâhil edilmiştir.

Türkiye'nin 2005-2017 yılları arasındaki bankacılık endeksi ve CDS primine göre uzun vadeli ülke notunu incelediğimizde ilk olarak 2005 yılsonunda Moody's tarafından verilen Ba3 seviyesindeki notunu görüyoruz. 2006-2007 ve 2008' de CDS primindeki düşüş ve bankacılık endeksindeki artış trendine rağmen ülkenin uzun vadeli kredi notu güncellenmemiştir. 
Grafik 6. Türkiye BIST Bankacılık Endeksi ve CDS Primi (USD)*

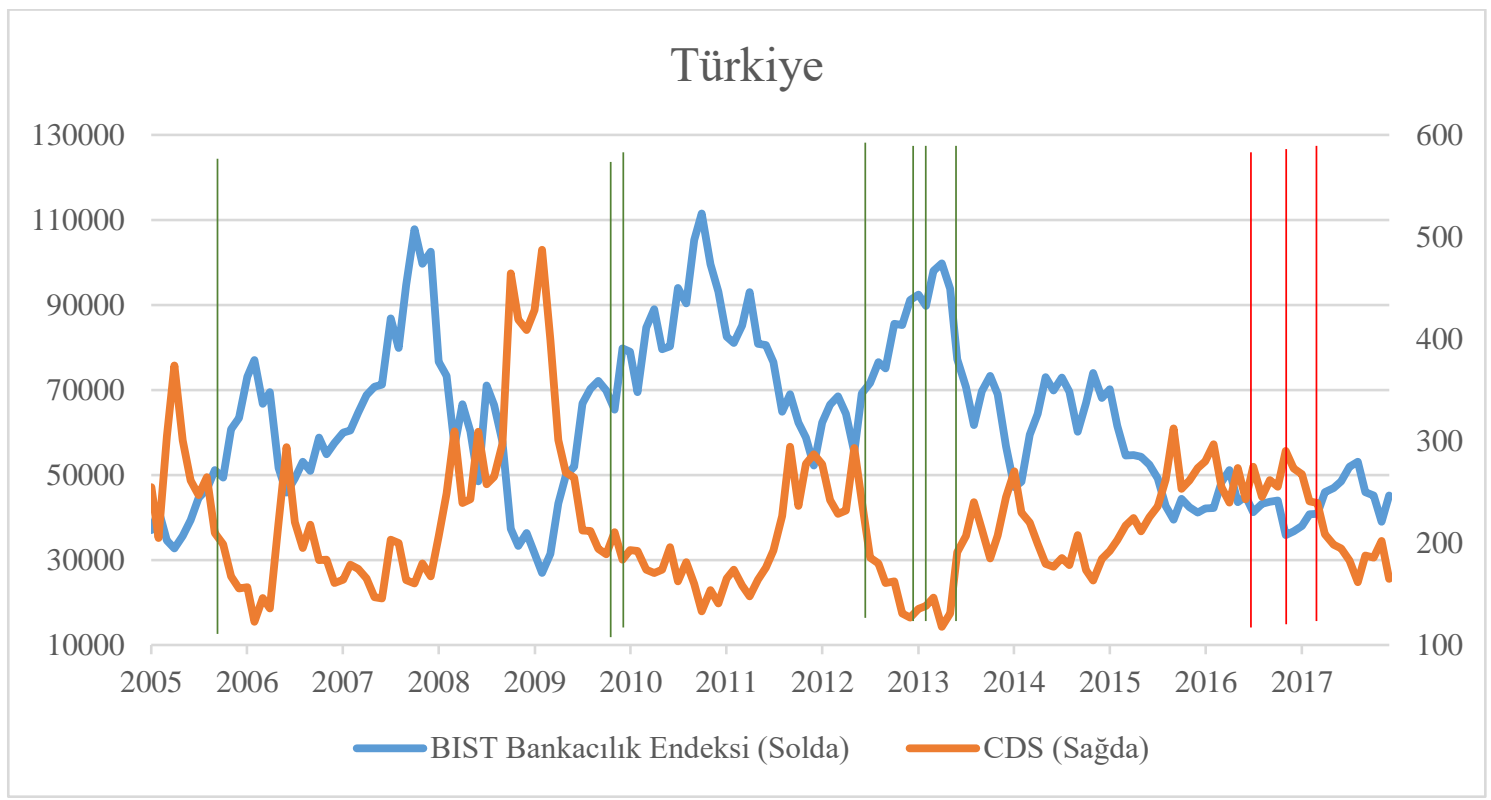

Kaynak: Bloomberg veri terminalinden sağlanan verilerle tarafımca oluşturulmuştur (31/08/2018).

* Grafikte yer alan dikey çizgiler not değişimlerinin gerçekleştiği tarihleri göstermektedir. Yeşille gösterilen dikey çizgiler not artışını ifade ederken, kırmızıyla gösterilen dikey çizgiler not düşüşünü ifade etmektedir.

2009 yılsonunda Fitch ülke notunu bir kademe arttırarak BB+'ya yükseltmiştir. 2010 yılı Ocak ayında Moody's de kredi notunu bir kademe arttırarak Ba2'ye yükseltmiştir. 2011 yılında yine bankacılık endeksinde yükseliş ve CDS priminde yaşanan düşüş dikkat çekmektedir fakat üç derecelendirme kuruluşu da ülke notunu güncellememiştir.

2012 yılı Haziran ayında Moody's ülke notunu bir kademe daha arttırarak Ba1'e yükseltmiştir. Fitch ise ülke notunu Kasım ayında BBB-'ye yükselterek yatırım yapılabilir seviyeye taşıyan ilk kredi derecelendirme kuruluşu olmuştur. 2013 yılı Mart ayında S\&P ülke notunu BB+'ya yükselterek spekülatif seviyede bırakmıştır. Mayıs ayında ise Moody's ülke notunu Baa3'e yükselterek yatırım yapılabilir seviyeye yükselten ikinci derecelendirme kuruluşu olmuştur.

2010 yılı itibariyle GSYH ile kişi başına düşen milli gelirde görülen ivmeye ve rezervlerdeki artışa CDS priminin tepkisi piyasa koşullarında yaşanırken kredi derecelendirme kuruluşlarının gecikme sorununu 2012 yılsonu ve 2013 yılbaşında gelen not güncellemeleriyle görüyoruz.

Türkiye'nin uzun vadeli kredi notu Fitch ve Moody's tarafından yatırım yapılabilir seviyede değerlendirilirken S\&P tarafından spekülatif seviyede açıklanmaya devam edilmiştir. Burada kredi derecelendirme kuruluşlarına; standartlaşmamış ve şeffaf olmayan kredi derecelendirme metodolojileri kullandıklarına dair eleştiri yönlendirilmektedir. Aynı kurum ya da ülkeye ait notların farklı olması nedeniyle derecelendirme kuruluşları eleştirilmektedir. Standart ve nesnel bir görüş sunması beklenen derecelendirme kuruluşlarının derecelendirme süreci açık bir matematik denkleme dayanmadığı için puanlama tamamen öznel değerlendirmeleri içermektedir. Birbirinden farklı derecelendirme notları yatırımcılarda fikir kargaşasına neden olmakta ve derecelendirme kuruluşlarının kasıtlı olarak not güncellemesine gitmediği yorumlarını doğurmaktadır (Akçayır, 2013).

2016 yılında S\&P ve Moody's ülkenin kredi notunu birer basamak düşürmüştür. Moody's not indirimine gerekçe olarak Türkiye'nin yüksek dış borcunu göstermiş ve büyüme ile kurumsal sağlamlıkta zayıflama olduğunu iddia etmiştir. Fakat üçüncü bölümde incelediğimiz makroekonomik verilerde GSYH'de 2015 yılına göre artış yaşandığını ve dış borcun da neredeyse bir önceki yılda gerçekleşen seviyelerde olduğunu görmüştük. Moody's ülkenin uzun vadeli notunu Ba1 ile tekrar spekülatif seviyeye çekerken S\&P 
kredi notunu BB olarak açıklamıştır. Not indirimlerini 2017 yılı Ocak ayında ülke notunu BB+ ile spekülatif seviyeye çeken Fitch takip etmiştir. 2016 yılında ülkemizde yaşanan darbe girişiminin hemen ardından yayınlanan not indirimlerinin yaşandığı dönemde CDS priminin 2014 yılındaki rakamlara yakın seviyelerde olduğu grafikten görülmektedir. 2016 yılı Aralık ayından itibaren düşüşe geçen CDS primi ve toparlanan bankacılık endeksine rağmen üç büyük kredi derecelendirme kuruluşunca ülkenin uzun vadeli kredi notu spekülatif seviyede bırakılmıştır.

Üçüncü bölümde incelenen makroekonomik verilerde not indirimi yaşanan 2016 yılsonu makrolarda bir önceki yıla göre kayda değer bir bozulma görülmemiştir. GSYH rakamında ilgili yılda 2015 yılına göre artış yaşanmıştır. Mevcut not indirimlerinin siyasi gerekçelerle verildiği aşikârdır. Kredi derecelendirme kuruluşları Türkiye'yi değerlendirirken siyasi riski her zaman göz önünde bulundurmakta ve bölgesel ön yargıları gereği Türkiye'deki riskleri olduğundan çok daha üst düzeyde değerlendirmektedir.

S\&P tarafından Türkiye için açıklanan kredi notlarına özellikle bakmak gerekirse çalışmada ele alınan 2005-2017 yılları arasında ülkenin uzun vadeli kredi notunun BB seviyesinde tutulduğu ve sadece 2013 yılında BB+'ya yükseltildiği görülüyor. Makroekonomik verilerdeki değişikliğe karşı derecelendirme kuruluşunun not güncellememesi sağlıklı bir değerlendirme yapmadığı kaygısı uyandırmaktadır. Kredi derecelendirme kuruluşlarına yönlendirilen bir başka eleştiri de re'sen yapılan derecelendirmelerdir. Basel II uzlaşıSı ve SEC'in kredi derecelendirme kuruluşlarına yönelik mevzuatları gereği, bir banka ya da ülkeyi karşı taraf istemeden derecelendirme yetkisine sahiptirler. Verdikleri derecelendirme hizmeti karşılığında, yüklü paralar alan bu kuruluşların herhangi bir ücret talep etmeden, re'sen derecelendirme yapmasının arkasında birçok ince hesaplar bulunduğuna yönelik eleştiriler bulunmaktadır. S\&P Türkiye için 2013 yılından bu yana re'sen değerlendirmede bulunmaktadır.

\section{Sonuç}

Kredi derecelendirme kuruluşları ülkelerin ya da o ülkedeki finansal kuruluşların ve firmaların borçlarını tam ve zamanında geri ödeme kapasitesini belirler, ilgililere ve yatıımcılara sunar. Yatırımcıların yatırım kararlarına etkileyen kredi notları ülkeler için büyük öneme sahiptir. Düşük kredi notuna sahip olan ülke, dış piyasalardan daha yüksek maliyetle kaynak temin edeceğinden ekonomik gelişimi olumuz etkilenecektir. Kredi derecelendirme kuruluşları bu sebeple ülkelerin ekonomik gelişimine ve sermaye kapasitesine önemli derecede etkide bulunmaktadır. Özellikle gelişmekte olan ülkelerin sahip olduğu düşük tasarruf oranları nedeniyle yatırımların finanse edilmesinde yaşanan sıkıntılar negatif notlarla ülkelerin ekonomik krize sürüklenmesine neden olmaktadır.

Çalışmada ele alınan ülkelerin uzun vadeli notları endeks verileri ve CDS primiyle, seçilen bankaların kredi notları ise belirli finansal oranlar yardımıyla değerlendirildikten sonra kredi derecelendirme kuruluşları tarafından verilen notların çalışmada incelenen ülkelerin durumunu genel olarak doğru tespit etmekten uzak olduğu görülmüştür.

Brezilya'nın uzun vadeli ülke notunda 2015-2017 yılları arasında yapılan not indirimlerinin CDS primlerinin zirve yaptı̆̆ı noktada yapılması bize kredi derecelendirme kuruluşlarının piyasayı takipte geciktiklerini göstermektedir. Oligopol durumdaki kredi derecelendirme kuruluşlarının önceden önlem alınmasına imkan tanıyacak güncel bilgi arzı konusunda çok hassas olamadığını da hatırlatmaktadır. Brezilya'da araştırma için seçtiğimiz Banka Mercantil'in kredi notları incelenirken S\&P'nin dört ay içinde üç kere not değişimine gittiği görülmüş ve yaptığı bu peş peşe not indirimleriyle banka notunun belirlenmesinde doğru yol izlenmediği düşünülmüştür. Kredi derecelendirme kuruluşlarına yöneltilen eleştirilerden biri de yanlış ya da eksik derecelendirme yaptıklarına yöneliktir. Yanlış derecelendirme işleminin kanıtı, kısa bir süre önce derecelendirilen banka ya da ülkenin kısa bir sürenin ardından tekrar derecelendirilerek birden fazla not artırımı ya da not indirimi yapılmasıdır. 2015-2017 yılları arasında gerçekleşen not indirimlerinin CDS primlerinin zirve yaptığı noktada yapılması kredi derecelendirme kuruluşlarının piyasayı takipte geciktiklerinin bir göstergesi olarak kabul edilebilir. Bu durum aynı zamanda oligopol durumdaki kredi derecelendirme kuruluşlarının önceden önlem alınmasına imkan tanıyacak güncel bilgi arzı konusunda çok hassas olamadığı eksikliğini gösteriyor. 
Güney Afrika'nın uzun vadeli kredi notu incelendikten sonra çıkarılan sonuç; kredi derecelendirme kuruluşlarının ülke notunu spekülatif seviyeye indirmeye karar vermelerinin gecikmiş olduğuna yöneliktir. Kredi derecelendirme kuruluşlarının piyasayı geriden takip etmeleri ve gerçekleşen olaylar üzerinden notları revize etmeleri nedeniyle CDS primlerinin ülkenin risk durumunu daha iyi yansıttığı kanısı güçlenmektedir. Reyting notu çoğu kez ya geç kalmış ya da erken belirlemelerin izlerini taşıyabiliyor fakat CDS primi her an yeniden arz ve talebe göre belirlendiği için piyasanın anlık reaksiyonunu yansıtmaktadır. CDS primlerinin ülke piyasalarını analiz etmede daha bağımsız ve tutarlı oldukları, özellikleri dolayısıyla da kredi notlarından daha avantajı bir yapıya sahip oldukları söylenebilir. Kredi derecelendirme kuruluşlarının piyasadaki dalgalanmaları geç fark etmeleri, olacak olana göre değil olana göre not verdikleri eleştirisini de beraberinde getirmektedir. Bu husus derecelendirme faaliyetleri için tanımlanan "geleceğe ilişkin yapılan tahminlerdir" ibaresiyle çelişmektedir.

Hindistan'ın analizinde ise incelenen dönemde ülkenin makroekonomik veriler açısından olumlu bir görünüm sergilemesine rağmen kredi derecelendirme kuruluşlarınca aşırı ihtiyatlı davranılarak not güncellemesine gidilmediği tespit edilmiştir. Bu durum kredi derecelendirme kuruluşlarının not artırımı konusunda gelişmekte olan ülkelerde isteksiz davrandığının bir kanıtı olarak kabul edilebilir.

Meksika'da ise incelenen makroekonomik veriler ışı̆̆ında kredi notlarında tam tersi bir durum yaşandığı görülmüştür. Ülkenin not artışını takiben GSYH'deki düşüş ve enflasyon oranındaki artışa rağmen kredi notunda herhangi bir güncelleme gerçekleştirilmediği tespit edilmiştir. Aynı dönemde ülkenin CDS priminde ise artış yaşanmıştır.

2015 yılında ülke CDS priminin en yüksek olduğu seviyede gelen not indirimi ilerleyen yıllarda CDS primi düştüğünde ve makroekonomik veriler; GSYH, döviz rezervi ve cari denge gibi rakamlarda iyileşme görülmesine rağmen güncellenmemiştir.

Rusya'nın kredi notu incelenirken dikkat çeken olay ise, çalışma için seçilen Sber Bank'ın karlıık oranlarındaki ve hisse fiyatındaki artışa rağmen kredi notunun düşürülmesi oluyor. Ülke notunun, banka notları bakımından bir tavan oluşturması ve döviz cinsinden banka notunun ülke notunu geçememesi derecelendirme sürecinde önümüze çıkan başka bir olumsuzluktur. Derecelendirme kuruluşlarının ülke ekonomisi için verdikleri ülke tavan notları o ülkede faaliyet gösteren birçok özel kuruluşun borçlanma imkanını büyük oranda etkilemektedir. Ülke varlıklarından çıkan yatırım fonları ve likiditenin azalmasıyla ülkenin borçlanma imkanı azalmakta ve yükümlülüklerini yerine getirmekte zorlanmaktadır. Sonuç olarak ülke notunun düşürülmesiyle ülkede faiz oranları yükselmekte ve daha yüksek maliyetli borçlanmaya zorlanan ülkelerde risk de artmaktadır. Kredi derecelendirme kuruluşlarınca ülke notunun düşürülmesi sonucu ülkenin ekonomik koşulları bozulmakta ve bozulan ekonomik koşulların kötüleşmesi sonucu kredi notu daha da fazla düşmektedir. Bu olumsuz tablo ile bankalar için bir tavan oluşturan ülke notunun düşmesi sonucu banka notları da hızla düşmektedir. Kelebek etkisi olarak nitelendirilen bu olay krizin etkisini, süresini ve şiddetini arttırmaktadır

Çalışma sonucunda incelenen altı tane gelişmekte olan ülke ve on beş banka için aldıkları notlar değerlendirilirken kredi derecelendirme kuruluşlarının şeffaf, dinamik, hassas olmayan notlar açıkladıklarını ifade etmek mümkündür. Bu durum Bheenick (2005), lyengar (2010) ve Gehring ve Fuchs (2017) elde ettikleri sonuçlar ile de uyumludur. Buna ilave olarak rekabet eksikliğinin bulunduğu piyasa şartlarında verdikleri notlarla krizleri öngöremedikleri gibi gecikmeli davranmaları nedeniyle yaşanan krizlerin olumsuz etkilerini daha da derinleştirdikleri söylenebilir. Bu ise Ferri vd. (1999) ve Reisen ve Von Maltzan (1999) yaptıkları çalışmalarda ifade ettikleri bulgular ile örtüşmektedir.

Kredi derecelendirme kuruluşları gerek oligopolist yapıları gerekse büyük çoğunluğun tek ülke kökenli oluşu nedeniyle bağımsızlıkları konusunda eleştiriye maruz kalmaktadırlar. Kredi derecelendirme kuruluşlarına alternatif arayışlar içerisine giren piyasaların en çok rağbet ettiği araç ise CDS'dir. CDS primleri serbest piyasa şartları altında oluştuğu için ülkelerin risk durumlarını bağımsız bir kuruluş gibi ölçmektedir ve bu da yatırımcılara daha güvenilir bir yapı sunmaktadır. CDS primleri sayesinde yatırımcılar, yatırım yapmaları halinde üstlenecekleri riskler hakkında bilgi sahibi olmaktadır. CDS primleri ülke riskini kamuoyuna aktardığı için kullanışlı ve tercih edilen bir gösterge olarak kabul görmektedir. 


\section{Beyan ve Açıklamalar (Disclosure Statements)}

1. Bu çalışmanın yazarları, araştırma ve yayın etiği ilkelerine uyduklarını kabul etmektedirler (The authors of this article are admitted that they complied with the principles of research and publication ethics).

2. Yazarlar tarafından herhangi bir çıkar çatışması beyan edilmemiştir (No potential conflict of interest was reported by the authors).

3. Bu çalışma, intihal tarama programı kullanılarak intihal taramasından geçirilmiştir (This article was screened for potential plagiarism using a plagiarism screening program).

\section{Kaynaklar}

Akçayır, Ö. (2013). Uluslararası kredi derecelendirme kuruluşları ve güvenirliklerinin sorgulanması: Türkiye'nin kredi derecelendirme geçmişi ve bugünü (1992-2012). Süleyman Demirel Üniversitesi Sosyal Bilimler Enstitüsü, Yüksek Lisans Tezi, Isparta.

Aksoylu, E., \& Görmüş, ş. (2018). Gelişmekte olan ülkelerde ülke riski göstergesi olarak kredi temerrüt swapları: Asimetrik nedensellik yöntemi. Ekonomik ve Sosyal Araştırmalar Dergisi, 14(1), 15-33.

Balıkçıŏlu, E., \& Yılmaz, H. (2013). Ülkelerin Finansal açıdan kredi notlarını etkileyen faktörler ve kredi derecelendirme kuruluşlarının bu faktörler çerçevesinde değerlendirilmesi. Maliye Dergisi(165), 163-188.

Bissoondoyal-Bheenick, E. (2005). An analysis of the determinants of sovereign ratings. Global Finance Journal, 15(3), 251-280.

Cantor, R., \& Packer, F. (1996). Determinants and impact of sovereign credit ratings. Economic Policy Review, 2(2), 3753.

Dinler, Z. (2015). iktisada giriş. Bursa: Ekin Kitabevi Yayınları.

Duran, M., \& Kucuksarac, D. (2017). Linkages between credit spreads and credit ratings. Research Notes in Economics, Central Bank of The Republic of Turkey.

Eğilmez, M. (2016). Türkiye'nin kredi notu ve CDS primi. http://www.mahfiegilmez.com/2016/07/turkiyenin-kredi-notuve-cds-primi.html (Erişim Tarihi: 01/10/2018).

Ersan, i., \& Günay, S. (2009). Kredi Riski göstergesi olarak kredi temerrüt swapları (CDS) ve kapatma davasının Türkiye riski üzerine etkisine dair bir uygulama. Bankacılar Dergisi, 71, 3-22.

Ferri, G., Liu, L. G., \& Stiglitz, J. E. (1999). The procyclical role of rating agencies: Evidence from The East Asian Crisis. Economic Notes, 28(3), 335-355.

Fuchs, A., \& Gehring, K. (2017). The home bias in sovereign ratings. Journal of The European Economic Association, 15(6), 1386-1423.

Fulghieri, P., Strobl, G., \& Xia, H. (2013). The economics of solicited and unsolicited credit ratings. The Review of Financial Studies, 27(2), 484-518.

Gültekin-Karakaş, D., Hisarcıklılar, M., \& Öztürk, H. (2011). Sovereign risk ratings: Biased Toward developed countries? Emerging Markets Finance and Trade, 47(Sup2), 69-87.

Iyengar, S. (2010). Are sovereign credit ratings objective and transparent? IUP Journal of Financial Economics, 8(3), 722.

Jaramillo, L., \& Tejada, M. (2011). Sovereign Credit ratings and spreads in emerging markets: Does investment grade matter? IMF Working Papers, 1-17.

Kalbaska, A., \& Gątkowski, M. (2012). Eurozone sovereign contagion: Evidence from the CDS market (2005-2010). Journal of Economic Behavior \& Organization, 83(3), 657-673.

Kargi, B. (2014). Uluslararası Kredi derecelendirme kuruluşları ve Türkiye'nin kredi notu üzerine gözlemler (1998-2013). Journal of Academic Social Science Studies, 7(1), 351-370.

Kunovac, D., \& Ravnik, R. (2017). Are sovereign credit ratings overrated? Comparative Economic Studies, 59(2), 210-242.

Mellios, C., \& Paget-Blanc, E. (2006). Which factors determine sovereign credit ratings? The European Journal of Finance, 12(4), 361-377.

Pan, J., \& Singleton, K. J. (2008). Default and recovery implicit in the term structure of sovereign CDS spreads. The Journal of Finance, 63(5), 2345-2384. 
Reinhart, C. M. (2002). Sovereign Credit ratings before and after financial crises. In Ratings, Rating Agencies and The Global Financial System (pp. 251-268), Springer.

Reisen, H., \& Von Maltzan, J. (1999). Boom and bust and sovereign ratings. International Finance, 2(2), 273-293.

Remolona, E. M., Scatigna, M., \& Wu, E. (2008). The Dynamic pricing of sovereign risk in emerging markets: Fundamentals and risk aversion. The Journal of Fixed Income, 17(4), 57-71.

Stulz, R. M. (2010). Credit default swaps and the credit crisis. Journal of Economic Perspectives, 24(1), 73-92.

Ulusoy, A., \& Yılmaz, H. (2017). Kredi notu eleştirilerini test eden mekanizma: CDS primleri. Ekonomik ve Sosyal Araştırmalar Dergisi, 13(1), 61-77.

Williams, G., Alsakka, R., \& Ap Gwilym, O. (2013). The impact of sovereign rating actions on bank ratings in emerging markets. Journal of Banking \& Finance, 37(2), 563-577. 
This Page Intentionally Left Blank 